УДК 304: 2

УСТИНКИН Сергей Васильевич - доктор исторических наук, профессор; директор Приволжского филиала ФНИСЦ РАН (603000, Россия, г. Нижний Новгород, Холодный пер., 4); начальник международной междисциплинарной научно-исследовательской лаборатории изучения мировых и региональных социально-политических процессов, научный руководитель Высшей школы международных отношений и мировой политики Нижегородского государственного лингвистического университета им. Н.А. Добролюбова (603950, Россия, г. Нижний Новгород, ул. Минина, 31a; sv.иstinkin@ gmail.com)

КУКОНКОВ Павел Иванович - кандидат социологических наук, старший научный сотрудник Приволжского филиала ФНИСЦ РАН (603000, Россия, г. Нижний Новгород, Холодный пер., 4; kukonkov_pavel@rambler.ru)

\title{
СОЦИАЛЬНО-ДЕМОГРАФИЧЕСКИЕ ПРОЦЕССЫ В СУБЪЕКТАХ РФ С РАЗЛИЧНОЙ ЭТНИЧЕСКОЙ СТРУКТУРОЙ: НАПРАВЛЕННОСТЬ И СПЕЦИФИКА (на примере Приволжского федерального округа)
}

\begin{abstract}
Аннотация. Авторы статьи исходят из того, что направленность и динамика изменений в социально-экономической сфере российских регионов во многом обусловлены демографической ситуацией, которая, в свою очередь, связана с особенностями этнической структуры. По мнению авторов, долговременные тенденции изменения рождаемости и смертности в России продолжают определяться значительным русским большинством, положение которого требует внимания и тщательного анализа, в частности сравнения с положением других этносов, проживающих в аналогичных условиях. В фокусе их внимания находятся субъекты Приволжского федерального округа с наиболее выраженными различиями этнической структуры. Основываясь на данных статистики и результатах социологических исследований, авторы приходят к выводу о необходимости регулярного отслеживания процесса накопления негативного потенциала в социально-демографической сфере регионов, чреватого разрушительными последствиями.
\end{abstract}

Ключевые слова: регион, этническая структура, социально-демографическая сфера, социально-демографические процессы

$\mathrm{C}$ оциально-экономическое развитие российских регионов во многом определяется составом, структурой и движением населения, от которых, в свою очередь, зависят наличие трудовых ресурсов, потребление товаров и услуг. Корректировка направленности и динамики развития региона в целом предполагает адекватное понимание демографической ситуации, учет рисков, связанных с накоплением негативного потенциала демографических процессов, что выступает важным условием принятия обоснованных и эффективных решений в этой сфере.

В послании Федеральному собранию в 2018 г. в числе приоритетных задач президент РФ В.В. Путин назвал не только стабилизацию численности населения России, но и обеспечение ее устойчивого естественного роста на основе увеличения рождаемости, сбережения народа и благополучия граждан ${ }^{1}$.

Следует подчеркнуть, что указанные задачи весьма далеки от своего раз-

1 Послание Президента Федеральному собранию. Сбережение народа России и его интеллекта как условие успешности российского государства. 1 марта 2018 г. Доступ: http:// www.kremlin.ru/events/president/news/56957 
решения, что подтверждают экспертные оценки, сделанные в последние два десятилетия: «постперестроечный период в России ознаменовался демографической катастрофой, получившей название "русский крест” " [Римашевская 1999]; «на данный момент демографическая ситуация в России - одна из наиболее удручающих в мире» [Халтурина, Коротаев 2006: 3]; «принимаемые Правительством страны меры пока не дают существенных результатов. Особенно резко сокращается население в Центральной России, нечерноземной зоне, Сибири, районах Крайнего Севера, Дальнего Востока» [Воронцов 2018]; «с 1989 года, то есть за 30 с лишним лет, население нашей страны (без учета Крыма) сократилось почти на $10 \%$, и дальнейший прогноз, к сожалению, неблагоприятный» [Винников 2021].

В.Э. Багдасарян отмечает особенность социально-демографических процессов в России: «Соотношение статистических показателей переписей 1989 и 2002 гг. обнаруживает резкий контраст репродуктивной динамики по отношению к различным национальностям РФ. Демографический кризис России удивительным образом совпадает с этноконфессиональными параметрами. Отнюдь не все из российских народов подпали под крест пересечения кривых рождаемости и смертности. При общем сокращении населения до уровня в 98,7\% по отношению к показателям 1989 г. численность русских понизилась до 96,7\%, то есть шла с двухпроцентным опережением среднестатистических кризисных характеристик» [Багдасарян 2006].

Очевидно, что, несмотря на имеющееся статистически значимое присутствие в общероссийском населении этнических групп, все еще имеющих существенно более высокую рождаемость, чем у русского народа, общие долговременные тенденции изменения рождаемости во всем населении России продолжают определяться русским большинством.

На наш взгляд, ситуация, в которой оказался русский народ, в настоящее время требует особого внимания власти. Поэтому существует настоятельная необходимость исследования направленности и специфики социально-демографических процессов, а также их связи с этнической структурой российских регионов. В связи с этим вызывает озабоченность изменение на протяжении длительного времени одного из основных показателей, характеризующих демографическую ситуацию в России (см. табл. 1).

Таблица 1

\section{Индексы детности (численность детей 0-9 лет на 1000 женщин в возрасте 20-49 лет) для некоторых народов по данным переписей населения Российской империи, СССР и Российской Федерации*}

\begin{tabular}{|l|c|c|c|c|c|c|c|c|c|}
\hline \multicolumn{1}{|c|}{ Этнос } & $\mathbf{1 8 9 7}$ & $\mathbf{1 9 2 6}$ & $\mathbf{1 9 3 9}$ & $\mathbf{1 9 5 9}$ & $\mathbf{1 9 7 0}$ & $\mathbf{1 9 7 9}$ & $\mathbf{1 9 8 9}$ & $\mathbf{2 0 0 2}$ & $\mathbf{2 0 1 0}$ \\
\hline Русские & 1310 & 1233 & 1191 & 863 & 703 & 667 & 759 & 384 & 450 \\
\hline Татары & 1454 & 1432 & 1592 & 1105 & 992 & 680 & 713 & 374 & 401 \\
\hline Чеченцы & 1904 & 1805 & 2174 & 2179 & 2256 & 1400 & 1267 & 942 & 1027 \\
\hline Евреи & 1490 & 795 & 824 & 337 & 296 & 305 & 343 & 225 & 286 \\
\hline Таджики & 982 & 1257 & 1564 & 1782 & 2637 & 2256 & 1977 & 1528 & 1158 \\
\hline
\end{tabular}

* Коллекция демографических показателей из ежегодного демографического доклада «Население России». - Демоскоп. № 877-878, 9-22 ноября 2020 г. Доступ: http://www. demoscope.ru/weekly/edd/edd_tab.php (проверено 18.05.2021).

Данные, представленные в табл. 1, свидетельствуют о неуклонном сни- 
жении на протяжении всего XX в. индекса детности среди русского населения, среди татар и евреев, причем снижение этого показателя значительно менее заметно среди чеченцев, а среди таджиков, напротив, он существенно вырос. На наш взгляд, эти факты весьма симптоматичны и предполагают целостный анализ демографических процессов, протекающих сегодня в России.

Анализ демографической ситуации в субъектах РФ, положения в них русского народа может быть реализован в процессе сравнения с положением других народов, проживающих рядом с русскими в аналогичных условиях Приволжского федерального округа (ПФО). В связи с этим особое исследовательское внимание мы сосредоточили на субъектах ПФО, в которых наблюдаются наиболее выраженные различия этнической структуры. К таким субъектам, на наш взгляд, относятся Башкирия, Чувашия, Татарстан, Кировская и Нижегородская обл. (см. табл. 2).

Таблица 2

Наиболее многочисленные этносы в субъектах ПФО, \%

\begin{tabular}{|l|c|c|c|c|c|c|}
\hline \multirow{2}{*}{\multicolumn{1}{|c|}{ Субъект ПФО }} & \multicolumn{7}{c|}{ Этнос } \\
\cline { 2 - 8 } & Русские & Башкиры & Татары & Чуваши & Марийцы & Мордва \\
\hline Башкирия & 36,1 & 29,5 & 25,4 & - & - & - \\
\hline Чувашия & 26,9 & - & 2,8 & 67,7 & - & - \\
\hline Татарстан & 39,7 & - & 53,2 & 3,1 & - & - \\
\hline Кировская обл. & 91,9 & - & 2,8 & - & 2,3 & - \\
\hline Нижегородская обл. & 95,1 & - & 1,4 & - & - & 0,6 \\
\hline
\end{tabular}

С целью проведения сравнительного анализа указанные регионы могут быть условно разделены на 3 группы:

- регионы с преобладанием русского населения (Кировская и Нижегородская обл.);

- регионы с преобладанием титульного населения (Татарстан, Чувашия);

- регион с равной представительностью нескольких этносов (Башкирия).

Мы предполагаем, что различия этнической структуры субъектов, накладываясь на различия в основных социально-экономических показателях, формируют существенные различия в условиях их жизнедеятельности. Реакцию населения на характер и направленность социально-экономических изменений в регионе фиксирует такой интегрированный показатель, как естественные рост/убыль населения. Представляется также достаточно убедительным предположение, что заметные различия условий жизнедеятельности в субъектах ПФО с различной этнической структурой закономерно сказываются на процессе изменения численности населения (см. табл. 3).

Анализ данных, представленных в табл. 3, свидетельствует о сравнительно более высокой убыли населения в субъектах ПФО с преобладанием русского населения. Наиболее заметен этот процесс в Кировской обл. Обращает на себя внимание то, что в 2018 г. в Нижегородской и Кировской обл. зафиксирована наиболее существенная убыль населения $(5-5,1 \%)$.

Некоторые эксперты считают, что меры демографической политики в последние годы внесли в прирост рождаемости гораздо больший вклад, чем действия других возможных факторов [Архангельский, Иванова, Рыбаковский 2016]. По мнению других экспертов, государственная политика не привела к увеличению числа рождений, а лишь ускорила претворение в жизнь уже име- 
Таблица 3

Изменение численности населения субъектов ПФО с различной этнической структурой (прирост за год; в \%)

\begin{tabular}{|l|c|c|c|c|c|c|c|c|c|}
\hline \multicolumn{1}{|c|}{ Субъект ПФО } & $\mathbf{2 0 1 0}$ & $\mathbf{2 0 1 1}$ & $\mathbf{2 0 1 2}$ & $\mathbf{2 0 1 3}$ & $\mathbf{2 0 1 4}$ & $\mathbf{2 0 1 5}$ & $\mathbf{2 0 1 6}$ & $\mathbf{2 0 1 7}$ & $\mathbf{2 0 1 8}^{* *}$ \\
\hline Башкирия & 0,1 & $-0,2$ & $-0,1$ & 0,2 & 0,1 & $-0,02$ & $-0,1$ & $-0,1$ & $-0,8$ \\
\hline Чувашия & $-0,4$ & $-0,3$ & $-0,3$ & $-0,3$ & $-0,2$ & $-0,1$ & $-0,1$ & $-0,4$ & $-2,0$ \\
\hline Татарстан & 0,1 & 0,4 & 0,5 & 0,4 & 0,4 & 0,4 & 0,4 & 0,2 & 0,5 \\
\hline Нижегородская обл. & $-0,6$ & $-0,3$ & $-0,2$ & $-0,3$ & $-0,3$ & $-0,3$ & $-0,4$ & $-0,4$ & $-5,1$ \\
\hline Кировская обл. & $-1,0$ & $-0,8$ & $-0,7$ & $-0,6$ & $-0,5$ & $-0,5$ & $-0,4$ & $-0,7$ & $-5,0$ \\
\hline
\end{tabular}

* Регионы России. Социально-экономические показатели. 2018: статистический сборник. М.: Росстат. 2018. С. 61-62. Знак (-) означает сокращение численности населения.

** Регионы России. Основные характеристики субъектов Российской Федерации. 2019: статистический сборник. М.: Росстат. 2019. С. 397-471.

ющихся репродуктивных планов семей, в то время как фертильность когорты осталась примерно на прежнем уровне [Захаров 2016].

Для оценки результативности демографической политики мы использовали динамику суммарных коэффициентов рождаемости, в которой фиксируются существенные различия коэффициентов рождаемости между субъектами ПФО с различной этнической структурой (см. табл. 4,5$)$.

Таблица 4

Общие коэффициенты рождаемости в субъектах ПФО с различной этнической структурой* (число родившихся на 1000 чел. населения)

\begin{tabular}{|l|c|c|c|c|c|c|c|c|c|}
\hline & $\mathbf{2 0 1 0}$ & $\mathbf{2 0 1 1}$ & $\mathbf{2 0 1 2}$ & $\mathbf{2 0 1 3}$ & $\mathbf{2 0 1 4}$ & $\mathbf{2 0 1 5}$ & $\mathbf{2 0 1 6}$ & $\mathbf{2 0 1 7}$ & $\begin{array}{c}\text { Мест0 } \\
\text { в РФ, 2017 }\end{array}$ \\
\hline ПФО & 12,4 & 12,4 & 13,3 & 13,3 & 13,3 & 13,3 & 12,8 & 11,1 & 5 \\
\hline Башкирия & 14,0 & 13,8 & 14,6 & 14,6 & 14,8 & 14,5 & 13,7 & 12,1 & 25 \\
\hline Чувашия & 12,9 & 12,9 & 14,0 & 14,0 & 13,9 & 13,8 & 13,2 & 11,3 & 42 \\
\hline Татарстан & 12,9 & 13,4 & 14,5 & 14,7 & 14,7 & 14,7 & 14,3 & 12,4 & 19 \\
\hline Нижегородская обл. & 10,9 & 11,0 & 11,8 & 11,8 & 11,9 & 12,3 & 11,9 & 10,5 & 58 \\
\hline Кировская обл. & 11,7 & 11,9 & 12,8 & 13,0 & 12,8 & 12,7 & 12,6 & 10,7 & 56 \\
\hline
\end{tabular}

* Регионы России. Социально-экономические показатели. 2018: статистический сборник. М.: Росстат. 2018. С. 59-60.

Данные, представленные в табл. 4, свидетельствуют о том, что в 20102017 гг. в областях ПФО с преобладанием русского населения (Кировская, Нижегородская) наблюдается сравнительно более низкий показатель числа родившихся на 1000 чел. населения. Весьма показательно, что именно в этих областях стабильно фиксируется сравнительно низкий суммарный коэффициент рождаемости (см. табл. 5).

Следует отметить, что Татарстан - единственный субъект в составе ПФО, в котором сохранился естественный прирост населения. Мы разделяем подход В.Ф. Валидовой, которая считает, что интерпретировать данные результаты необходимо с определенной долей осторожности, т.к. вычленить эффект влияния мер государственной политики на рождаемость достаточно сложно - репродуктивное поведение в регионе может быть обусловлено в некоторой 
Таблица 5

Суммарный коэффициент рождаемости в субъектах ПФО с различной этнической структурой (число детей на 1 женщину)

\begin{tabular}{|l|c|c|c|c|c|c|c|c|}
\hline & $\mathbf{2 0 1 0}$ & $\mathbf{2 0 1 1}$ & $\mathbf{2 0 1 2}$ & $\mathbf{2 0 1 3}$ & $\mathbf{2 0 1 4}$ & $\mathbf{2 0 1 5}$ & $\mathbf{2 0 1 6}$ & $\mathbf{2 0 1 7}$ \\
\hline РФ & 1,567 & 1,582 & 1,691 & 1,707 & 1,750 & 1,777 & 1,762 & 1,621 \\
\hline ПФО & 1,579 & 1,593 & 1,720 & 1,750 & 1,789 & 1,818 & 1,788 & 1,600 \\
\hline Башкирия & 1,771 & 1,739 & 1,859 & 1,887 & 1,948 & 1,939 & 1,860 & 1,696 \\
\hline Чувашия & 1,648 & 1,665 & 1,827 & 1,851 & 1,878 & 1,909 & 1,869 & 1,649 \\
\hline Татарстан & 1,601 & 1,652 & 1,796 & 1,832 & 1,844 & 1,863 & 1,855 & 1,652 \\
\hline Нижегородская обл. & 1,419 & 1,436 & 1,547 & 1,561 & 1,593 & 1,669 & 1,649 & 1,502 \\
\hline Кировская обл. & 1,592 & 1,641 & 1,808 & 1,868 & 1,885 & 1,913 & 1,943 & 1,696 \\
\hline
\end{tabular}

* Регионы России. Социально-экономические показатели. 2018: статистический сборник. М.: Росстат. 2018. С. 73-74.

степени этническими, религиозными и другими факторами, а также экономической и социальной ситуацией в республике [Валидова 2018].

Следует подчеркнуть, что сравнительно более высокие темпы процесса убыли населения в «русских» областях ПФО сохраняются до сих пор (см. табл. 6).

Таблица 6

Естественный прирост/убыль населения в январе-октябре 2020 г. ${ }^{*}$

\begin{tabular}{|l|c|c|}
\hline \multicolumn{1}{|c|}{ Субъект ПФО } & Чел. & $\begin{array}{c}\text { На } \mathbf{1 0 0 0} \text { чел. } \\
\text { населения }\end{array}$ \\
\hline Башкирия & -12729 & $-3,8$ \\
\hline Чувашия & -5486 & $-5,4$ \\
\hline Татарстан & -8252 & $-2,5$ \\
\hline Нижегородская обл. & -20062 & $-7,5$ \\
\hline Кировская обл. & -7305 & $-7,0$ \\
\hline
\end{tabular}

* Население. Естественный прирост и убыль населения. - Территориальный орган Федеральной службб государственной статистики по Нижегородской области. Доступ: https://nizhstat.gks.ru/folder/38725

Именно в Кировской и Нижегородской обл. стабильно фиксируется сравнительно более высокий уровень смертности (см. табл. 7).

Вполне закономерно, что именно Кировская и Нижегородская обл. лидируют по показателю естественной убыли населения (см. табл. 8).

Можно предположить, что описанные выше процессы во многом обусловлены состоянием системы медицинского обслуживания населения. Однако это предположение не подтверждается данными статистики (см. табл. 9, 10).

Данные, представленные в табл. 9, свидетельствуют о том, что в Нижегородской и Кировской обл. сравнительно больше больничных коек на 10 тыс. населения и сравнительно более развита сеть амбулаторно-поликлинических организаций (см. табл. 10). 
Таблица 7

Общие коэффициенты смертности в субъектах ПФО с различной этнической структурой (число умерших на 1000 чел. населения)

\begin{tabular}{|l|c|c|c|c|c|c|c|c|c|}
\hline & $\mathbf{2 0 1 0}$ & $\mathbf{2 0 1 1}$ & $\mathbf{2 0 1 2}$ & $\mathbf{2 0 1 3}$ & $\mathbf{2 0 1 4}$ & $\mathbf{2 0 1 5}$ & $\mathbf{2 0 1 6}$ & $\mathbf{2 0 1 7}$ & $\begin{array}{c}\text { Место в PФ, } \\
\mathbf{2 0 1 7}\end{array}$ \\
\hline ПФО & 15,0 & 14,3 & 14,0 & 13,9 & 13,9 & 13,9 & 13,6 & 13,1 & 8 \\
\hline Башкирия & 13,4 & 13,4 & 13,2 & 13,1 & 13,1 & 13,3 & 12,9 & 12,4 & 32 \\
\hline Чувашия & 14,5 & 13,6 & 13,3 & 13,1 & 13,3 & 13,1 & 13,2 & 12,6 & 38 \\
\hline Татарстан & 13,1 & 12,4 & 12,2 & 12,1 & 12,2 & 12,0 & 11,6 & 11,3 & 21 \\
\hline Нижегородская область & 17,9 & 16,4 & 16,1 & 15,9 & 15,9 & 15,5 & 15,4 & 14,7 & 69 \\
\hline Кировская область & 16,7 & 15,8 & 15,6 & 15,4 & 15,1 & 15,2 & 14,9 & 14,5 & 65 \\
\hline
\end{tabular}

* Регионы России. Социально-экономические показатели. 2018: статистический сборник. М.: Росстат. 2018. С. 63-64.

Таблица 8

Коэффициенты естественного прироста/убыли населения в субъектах ПФО с различной этнической структурой на 1000 чел. населения

\begin{tabular}{|l|c|c|c|c|c|c|c|c|}
\hline & $\mathbf{2 0 1 0}$ & $\mathbf{2 0 1 1}$ & $\mathbf{2 0 1 2}$ & $\mathbf{2 0 1 3}$ & $\mathbf{2 0 1 4}$ & $\mathbf{2 0 1 5}$ & $\mathbf{2 0 1 6}$ & $\mathbf{2 0 1 7}$ \\
\hline ПФО & $-2,6$ & $-1,9$ & $-0,7$ & $-0,6$ & $-0,6$ & $-0,6$ & $-0,8$ & $-2,0$ \\
\hline Башкирия & 0,6 & 0,4 & 1,4 & 1,5 & 1,7 & 1,2 & 0,8 & $-0,3$ \\
\hline Чувашия & $-1,6$ & $-0,7$ & 0,7 & 0,9 & 0,6 & 0,7 & 0,0 & $-1,3$ \\
\hline Татарстан & $-0,2$ & 1,0 & 2,3 & 2,6 & 2,5 & 2,7 & 2,7 & 1,1 \\
\hline Нижегородская область & $-7,0$ & $-5,4$ & $-4,3$ & $-4,1$ & $-4,0$ & $-3,2$ & $-3,5$ & $-4,2$ \\
\hline Кировская область & $-5,0$ & $-3,9$ & $-2,8$ & $-2,4$ & $-2,3$ & $-2,5$ & $-2,3$ & $-3,8$ \\
\hline
\end{tabular}

* Регионы России. Социально-экономические показатели. 2018: статистический сборник. М.: Росстат. 2018. С. 71-72.

Таблица 9

Медицинская система в субъектах ПФО с различной этнической структурой*

\begin{tabular}{|c|c|c|c|c|c|c|c|c|c|}
\hline \multirow{2}{*}{ Субъект ПФО } & \multicolumn{9}{|c|}{$\begin{array}{c}\text { Число больничных коек } \\
\text { на } 10000 \text { чел. населения }\end{array}$} \\
\hline & 2010 & 2011 & 2012 & 2013 & 2014 & 2015 & 2016 & 2017 & 2018 \\
\hline Башкирия & 86 & 85 & 85 & 81 & 81 & 80 & 79 & 78 & 77 \\
\hline Чувашия & 89 & 89 & 88 & 88 & 85 & 84 & 83 & 83 & 83 \\
\hline Татарстан & 78 & 77 & 75 & 72 & 66 & 66 & 65 & 63 & 63 \\
\hline Нижегородская обл. & 103 & 106 & 104 & 103 & 98 & 89 & 87 & 88 & 90 \\
\hline Кировская обл. & 111 & 106 & 110 & 102 & 95 & 90 & 88 & 87 & 88 \\
\hline
\end{tabular}

* Регионы России. Основные характеристики субъектов Российской Федерации. 2019: статистический сборник. М.: Росстат. 2019. С. 397-471. 
Таблииа 10

Медицинская система в субъектах ПФО с различной этнической структурой ${ }^{*}$

\begin{tabular}{|c|c|c|c|c|c|c|c|c|c|}
\hline \multirow[t]{2}{*}{ Субъект ПФО } & \multicolumn{9}{|c|}{$\begin{array}{c}\text { Мощность амбулаторно-поликлинических организаций, } \\
\text { посещений в смену } \\
\text { на } 10000 \text { чел. населения }\end{array}$} \\
\hline & 2010 & 2011 & 2012 & 2013 & 2014 & 2015 & 2016 & 2017 & 2018 \\
\hline Башкирия & 240 & 242 & 247 & 254 & 256 & 257 & 259 & 261 & 263 \\
\hline Чувашия & 301 & 306 & 311 & 313 & 314 & 324 & 325 & 332 & 335 \\
\hline Татарстан & 224 & 242 & 248 & 244 & 265 & 238 & 241 & 243 & 242 \\
\hline Нижегородская область & 256 & 262 & 264 & 272 & 277 & 290 & 303 & 293 & 297 \\
\hline Кировская область & 254 & 258 & 273 & 272 & 279 & 280 & 280 & 288 & 294 \\
\hline
\end{tabular}

* Регионы России. Основные характеристики субъектов Российской Федерации. 2019: статистический сборник. М.: Росстат. 2019. С. 397-471.

В связи с описанными выше изменениями в социально-демографической сфере представляется вполне закономерным стремление власти заместить убывающее население прежде всего в субъектах ПФО, для которых характерны негативные социально-демографические процессы. В частности, в Нижегородской обл. в 2010-2013 гг. наблюдался высокий миграционный прирост. Вместе с тем в последние годы в связи с нарастающим экономическим кризисом этот процесс заметно сократился. Исключение составляет лишь Татарстан (см. табл. 11).

Таблица 11

Миграционный прирост/убыль в субъектах ПФО с различной этнической структурой (на 10000 чел. населения)*

\begin{tabular}{|l|c|c|c|c|c|c|c|c|}
\hline & $\mathbf{2 0 1 0}$ & $\mathbf{2 0 1 1}$ & $\mathbf{2 0 1 2}$ & $\mathbf{2 0 1 3}$ & $\mathbf{2 0 1 4}$ & $\mathbf{2 0 1 5}$ & $\mathbf{2 0 1 6}$ & $\mathbf{2 0 1 7}$ \\
\hline РФ & 19 & 22 & 21 & 21 & 19 & 17 & 18 & 14 \\
\hline ПФО & -12 & -4 & -6 & -5 & -2 & -8 & -5 & -12 \\
\hline Башкирия & 2 & -23 & -22 & 7 & -11 & -15 & -18 & -6 \\
\hline Чувашия & -27 & -22 & -36 & -36 & -21 & -19 & -7 & -25 \\
\hline Татарстан & 10 & 32 & 26 & 15 & 19 & 9 & 15 & 12 \\
\hline Нижегородская обл. & 11 & 21 & 21 & 15 & 5 & 2 & -3 & 2 \\
\hline Кировская обл. & -54 & -42 & -39 & -38 & -27 & -28 & -21 & -28 \\
\hline
\end{tabular}

* Регионы России. Социально-экономические показатели. 2018: статистический сборник. М.: Росстат. 2018. С. 87-88.

Демографическая ситуация в регионе во многом определяется ситуацией в крупных городах, которые по большей части являются центрами - столицами региона: «Если взять 15-летний период, то Казань показала наибольший при- 
рост населения среди городов ПФО - на 145 тыс. человек. На втором месте - Уфа, подросшая на 99 тыс. граждан, на третьем - Пермь с 62 тысячами. А вот Нижний Новгород, наоборот, потерял 31 тыс. человек. С 2014 по 2018 год внутрирегиональный миграционный прирост населения Казани (разность между числом прибывших и выбывших) составил 11,9 тыс. человек. В Нижнем Новгороде сальдо миграции отрицательное: минус 2,7 тыс. человек» 1 .

Численность постоянного населения Нижегородской обл. на 1 января 2019 г. составила 3214,6 тыс. чел., а на 1 октября 2019 г. - 3206,7 тыс. чел. (снижение - $0,2 \%)$. В целом по области уровень смертности превышает уровень рождаемости в 1,6 раза. По сравнению с аналогичным периодом предыдущего года в январе-сентябре 2019 г. на 3,8\% уменьшилось число умерших, и на 9,4\% уменьшилось число родившихся, естественная убыль увеличилась на 7,0\% 2 .

В последние годы в Нижегородской обл. наметился миграционный отток населения, в первую очередь в столичный регион, увеличилась доля выезжающих за пределы страны. Эксперты отмечают, что эти процессы отрицательно влияют на демографическую ситуацию в регионе, поскольку уезжают молодые люди в репродуктивном возрасте, часто это люди с высшим образованием в трудоспособном возрасте [Аракчеева, Кривдина 2018]. Существует и другой подход к оценке эти процессов, в рамках которого ПФО и Нижегородская обл. рассматриваются как транзитная территория, расположенная на пути устойчивого внутрироссийского западного миграционного дрейфа, направленного в Центральный округ [Мкртчян 2015].

Анализ структуры миграционных потоков в Нижегородской обл. показывает, что на протяжении последних лет преобладает внутрирегиональная миграция, величина которой в зависимости от года колеблется в пределах от $56 \%$ до $61 \%$. В основном население переезжает в областной центр - Нижний Новгород и крупные города - Арзамас, Выксу, Кстово из малых городов или сельских населенных пунктов ${ }^{3}$.

Наиболее высокий миграционный прирост в Нижегородской обл. наблюдался из стран СНГ (1 760 чел.), наиболее значительный миграционный отток - в другие зарубежные страны (1 065 чел. $)^{4}$. За десять лет доля выехавших в другие страны возросла в 4 раза ${ }^{5}$. Достаточно очевидно, что негативные социально-демографические процессы в Нижегородской обл., как и в других субъектах ПФО, обусловлены совокупностью факторов, среди которых миграция не играет определяющую роль. Более того, миграция, используемая в своих интересах незначительной частью принимающего сообщества, одновременно создает для него немало существенных проблем, причем баланс «обретений» и «потерь» до сих пор не вполне очевиден.

Мы разделяем подход, в соответствии с которым на характер миграционных процессов разнонаправленное воздействие оказывает растущее неравенство.

1 Казань «сделала» Нижний в демографической гонке. Не пора ли переносить столицу ПФО? - Бизнес Online. 29 июня 2020 г. Доступ: https://www.business-gazeta.ru/article/473180 (проверено 18.05.2021).

2 Демографическая обстановка в Нижегородской области за январь - сентябрь 2019 года. Доступ: https://government-nnov.ru/?id=246461 (проверено 20.02.2021).

3 Регионы России. Социально-экономические показатели. 2011. Доступ: http://www.gks. ru/bgd/regl/B11_14p/Main.htm (проверено 10.02.2021).

4 Основные показатели социально-экономического положения муниципальных образований. - Территориальный орган Федеральной службы государственной статистики по Нижегородской области. Доступ: https://nizhstat.gks.ru/main_indicators (проверено 16.01.2021).

5 Регионы России. Социально-экономические показатели. 2011. Доступ: http://www.gks. ru/bgd/regl/B11_14p/Main.htm (проверено 10.11.2018). 
Результаты нашего исследования свидетельствуют о том, что в фокусе внимания большинства нижегородцев находится неравенство в распределении доходов, которое фиксируют более $2 / 3$ населения средних, малых городов и сельской местности. На втором месте по степени распространенности, по мнению нижегородцев, находится неравный доступ к здравоохранению, образованию, на третьем - неравенство жилищных условий ${ }^{1}$.

Необходимо отметить, что присутствие мигрантов не только повышает спрос на жилье, но и неизбежно повышает цены, особенно на качественное, удобное жилье. В школах крупных городов нередко вынуждены создавать особые классы для детей приезжих - трудовые мигранты из стран СНГ специально привозят с собой семьи, потому что здесь они могут получить более качественное лечение и образование. Вместе с тем мигранты слабо участвуют в создании и развитии инфраструктуры там, где они живут и работают, активно используя ее в своих интересах.

Влияние мигрантов на повседневную жизнь отмечает значительная часть населения Нижегородской обл. (см. табл. 12).

Таблица 12

Оценка населением Нижегородской обл. влияния мигрантов на повседневную жизнь города, поселения, \%

\begin{tabular}{|l|c|c|c|}
\hline $\begin{array}{c}\text { Насколько сильно влияет присутствие мигрантов } \\
\text { в вашем городе (поселении) на вашу жизнь }\end{array}$ & $\begin{array}{c}\text { Нижний } \\
\text { Новгород }\end{array}$ & $\begin{array}{c}\text { Средние и } \\
\text { малые города }\end{array}$ & $\begin{array}{c}\text { Сельская } \\
\text { местность }\end{array}$ \\
\hline Сильно влияет & 11,1 & 5,7 & 5,1 \\
\hline Влияет незначительно & 31,0 & 28,3 & 21,2 \\
\hline Практически не влияет & 44,4 & 53,3 & 53,4 \\
\hline Затрудняюсь ответить & 13,6 & 12,7 & 20,3 \\
\hline
\end{tabular}

Мы предполагаем, что заметные флуктуации миграционных потоков, выступая важным показателем благополучия социальной ситуации, оказывают дестабилизирующее влияние на социально-демографическую ситуацию в регионе, а слабо контролируемая миграция усложняет решение указанных проблем. Видимо, не случайно заметная часть населения отрицательно относится к мигрантам (см. табл. 13).

Таблица 13

Отношение к мигрантам населения Нижегородской обл., \%

\begin{tabular}{|l|c|c|c|}
\hline $\begin{array}{c}\text { Как вы относитесь к мигрантам из других стран } \\
\text { в нашей стране? }\end{array}$ & $\begin{array}{c}\text { Нижний } \\
\text { Новгород }\end{array}$ & $\begin{array}{c}\text { Средние и } \\
\text { малые города }\end{array}$ & $\begin{array}{c}\text { Сельская } \\
\text { местность }\end{array}$ \\
\hline Положительно & 18,5 & 12,0 & 11,9 \\
\hline Нейтрально & 62,9 & 62,0 & 68,6 \\
\hline Отрицательно & 18,7 & 26,0 & 19,5 \\
\hline
\end{tabular}

На наш взгляд, распространенность отрицательного отношения к мигрантам в средних и малых городах связана с комплексом социальных проблем, нако-

1 Здесь и далее представлены результаты социологического исследования в Нижегородской обл., которое проводилось в 2017-2018 гг. сотрудниками Приволжского филиала ФНИСЦ РАН. Выборка репрезентативная по основным социально-демографическим характеристикам. Отчет о научно-исследовательской работе «Приволжский федеральный округ в контексте современных социально-экономических вызовов». М., 2018. 
пившихся прежде всего в сфере труда этих городов: с нехваткой рабочих мест, отсутствием работы с достойной оплатой. В связи с этим значительное большинство их населения оценивает социально-экономическую целесообразность труда мигрантов как низкую или скорее низкую (см. табл. 14).

Таблица 14

Оценка населением социально-экономической целесообразности труда мигрантов в экономике города, поселения, \%

\begin{tabular}{|l|c|c|c|}
\hline \multicolumn{1}{|c|}{ Целесообразность } & $\begin{array}{c}\text { Нижний } \\
\text { Новгород }\end{array}$ & $\begin{array}{c}\text { Средние и } \\
\text { малые города }\end{array}$ & $\begin{array}{c}\text { Сельская } \\
\text { местость }\end{array}$ \\
\hline Низкая & 12,9 & 23,0 & 28,8 \\
\hline Скорее низкая & 26,8 & 35,3 & 29,7 \\
\hline Средняя & 37,3 & 28,3 & 30,5 \\
\hline Скорее высокая & 20,3 & 10,0 & 9,3 \\
\hline Высокая & 2,7 & 3,3 & 1,7 \\
\hline
\end{tabular}

По оценке экспертов, воздействие конкуренции с мигрантами за рабочие места испытывают $22,1 \%$ россиян, чаще всего - рядовые наемные работники $(31,7 \%)$, имеющие дополнительную занятость $(31,8 \%)$; самозанятые $(35,5 \%)$; люди со средним образованием (40\%); занятые в сфере строительства, общественного питания, торговли, сельского хозяйства (от 41,4\% до 27\%) [Покида, Зыбуновская 2017].

Привлечение мигрантов, временно отодвигающее назревшие социальнодемографические проблемы, влечет за собой возникновение ряда социальноэкономических проблем, усложняя многие уже имеющиеся. Дело в том, что мигранты чаще всего не ориентированы на интеграцию в принимающее сообщество и на развитие территории проживания: используя социальную инфраструктуру (дороги, транспорт, детские и медицинские учреждения), в создании и развитии которой они не принимали участия, они и впредь не намерены это делать. Рост нагрузки на социальную сферу, широкая распространенность напряжений внутри нее при определенных условиях может повлечь и уже влечет существенное ухудшение функционирования основных подсистем принимающего сообщества ${ }^{1}$.

\section{Список литературы}

Аракчеева О.В., Кривдина И.Ю. 2018. Миграции населения Нижегородской области. - Успехи современного естествознания. № 12-2. С. 339-344.

Архангельский В.Н., Иванова А.Е., РыбаковскийЛ.Л. 2016. Результативность демографической политики России. М.: Экон-Информ. 307 с.

Багдасарян В.Э. 2006. «Русский крест». Духовно-психологический надлом как фактор русской депопуляции. - Наш современник. № 6. Доступ: http://www. nash-sovremennik.ru/p.php? $\mathrm{y}=2006 \& \mathrm{n}=11 \& \mathrm{id}=7$ (проверено 01.05.2021)

Валидова А.Ф. 2018. Влияние демографической политики на показатели рож-

1 Отчет о научно-исследовательской работе Приволжского филиала ИС РАН в 2014 2016 гг. «Изучение динамики изменений социально-политической ситуации в различных регионах Приволжского федерального округа». ФНИСЦ РАН. 2017: отчет о НИР. Приволжский филиал ФНИСЦ РАН; рук. Устинкин С.В. Нижний Новгород. 2014. 74 с. Исполн.: Куконков П.И., Морозова Н.М., Самсонов А.И., Труфанов А.Ю. 
даемости в Российской Федерации и Республике Татарстан. - Регионология. Т. 26. № 3. С. 494-511.

Винников В. 2021. Война на уничтожение. Об экономических причинах сокращения населения России. - Завтра. 3 марта 2021. Доступ: https://zavtra. ru/blogs/poschitali_proslezilis_(проверено 01.05.2021).

Воронцов А.В. 2018. Демографическое состояние русского народа. - Здоровье - основа человеческого потенциала: проблемы и пути их решения. Т. 13. № 1. C. $33-45$.

Захаров С.В. 2016. Скромные результаты пронаталистской политики на фоне долговременной эволюции рождаемости в России. Часть 1. - Демографическое обозрение. Т. 3. № 3. С. 6-38.

Мкртчян Н.В. 2015. Пространственные особенности внутрироссийской миграции в постсоветский период. - Современные исследования миграции населения. Вып. 26 (под ред. Е.В. Донец, О.С. Чудиновских). М.: Изд-во МГУ. C. 94-111.

Покида А.Н., Зыбуновская Н.В. 2017. О тенденциях занятости работающего населения. - Социс. Социологические исследования. № 7. С. 54-59.

Римашевская Н. М. 1999. «Русский крест». - Природа. № 6. С. 3-10. Доступ: http://vivovoco.astronet.ru/VV/JOURNAL/NATURE/06_99/RUSSDEMO.HTM (проверено 01.05.2021).

Халтурина Д.А., Коротаев А.В. 2006. Русский крест: Факторы, механизмы и пути преодоления демографического кризиса в России. М.: КомКнига. 56 с.

USTINKIN Sergey Vasilyevich, Dr.Sci. (Hist.), Professor; Director of the Volga Branch of the Federal Center of Theoretical and Applied Sociology, Russian Academy of Sciences (4 Holodny Lane, Nizhny Novgorod, Russia, 603000; Head of the International Cross-Disciplinary Laboratory for Studies of Global and Regional Sociopolitical Processes, Scientific Director of the Higher School of International Relations and World Politics, Dobroljubov State Linguistics University of Nizhny Novgorod (31a Minina St, Nizhny Novgorod, Russia, 603155); sv.ustinkin@gmail.com)

KUKONKOV Pavel Ivanovich, Cand.Sci. (Soc.), Senior Researcher of the Volga Branch of the Federal Center of Theoretical and Applied Sociology, Russian Academy of Sciences (4 Holodny Lane, Nizhny Novgorod, Russia, 603000; kukonkov_pavel@rambler.ru)

\section{SOCIAL AND DEMOGRAPHIC PROCESSES IN SUBJECTS OF THE RUSSIAN FEDERATION WITH DIFFERENT ETHNIC STRUCTURES: ORIENTATION AND SPECIFICITY (on the example of the Volga Federal District)}

\footnotetext{
Abstract. The authors of the article assume that the direction and dynamics of changes in the socio-economic sphere of the Russian regions are largely due to the demographic situation, which, in turn, is related to the peculiarities of the ethnic structure. According to the authors, long-term trends in fertility and mortality in Russia continue to be determined by a large Russian majority, whose situation requires attention and careful analysis, in particular, in comparison with the situation of other ethnic groups living in similar conditions. Their focus is on the subjects of the Volga Federal District with the most pronounced differences in ethnic structure. Based on statistics and sociological research, the authors make a conclusion about the necessity of regular monitoring the process of accumulation of negative potential in the socio-demographic sphere of regions, which has devastating consequences.
}

Keywords: region, ethnic structure, socio-demographic sphere, socio-demographic processes 